\title{
PROFESSOR TITULAR
}

\author{
Head Professor
}

Alcino Lázaro da SILVA

Professor de Cirurgia e Emérito, UFMG

A Cátedra se foi com a reforma universitária e cada catedrático despediu-se com uma das duas condutas que adotava. $\mathrm{Na}$ primeira, havia um comandante que usava do poder conferido pelo concurso e não permitia que os subordinados progredissem, se titulassem e atendessem às suas expectativas ou sonhos. Com relação a esse, a reforma beneficiou a comunidade universitária, liberando-a do pseudointelectual. $\mathrm{Na}$ segunda conduta, a comunidade perdeu um grande valor que era o professor real e autêntico, criador de seguidores competentes e progressistas. Usava do poder para fazer crescer os subordinados, sem medo de substituição ou quebra da hierarquia. Com o seu desaparecimento perdeu muito a comunidade universitária. O professor, o mestre!

A reforma, desorientada, substituiu a cátedra pela titularidade. Criou o professor titular, sem defini-lo corretamente, como um substituto que não adquiria poder mas deveria cultivar a liderança natural e intelectual. Todos os titulares se vincularam aos departamentos, numa cópia mal inspirada nos do exterior e com uma característica políticoadministrativa, superior à intelectual ou facilitadora da criação de oportunidade para o crescimento de todos. Professor sem poder e sem a completa formação para fazer outros crescerem. O voto no departamento passou a imperar e substituir a necessária e indispensável hierarquia de competência.

A consequência foi dar aos mais jovens, aos oportunistas, ou aos menos competentes, o direito de votar e ser votado o que os levou a candidatar-se às chefias de departamentos colocando o titular no patamar horizontal e bloqueando os que eram e são os formadores de outros professores qualificados.

Os jovens não cresceram como deviam e os titulares se desmotivaram na formação de pessoal. A sorte da universidade brasileira foi a pósgraduação, uma grande tábua de salvação, em que se possibilitou o refúgio do titular para ela e a oportunidade dos bons se qualificarem e propiciar o crescimento de seguidores.

Nesse emaranhado de voto, demagogia, qualidade e hierarquia sobreviveram os autênticos, remanescendo os formadores de opinião e pessoal e os que possuem criatividade para imperar com o intelecto.

Julgo-me intrometido em fazer uma sequência de qualidades que o professor titular deve ter para preservar a universidade, na caminhada em busca da formação de pessoal e crescimento universitário. Substituir o poder pela hierarquia de competência.

Professor Titular é aquele que se diferencia dos seguidores ou orientandos pela competência, pelo caráter, pelo progresso profissional e pelo compromisso institucional. Enfim, usa o passado, dinamiza o presente e arquiteta o futuro.

O Titular deve aprender, exercitar e transferir: competência, equilíbrio, brio, moral ilibada e humildade para ter ascendência sobre colegas em formação.

Só consegue agregar seguidores aquele que cultiva qualidades que, no mínimo, estejam no mesmo nível do grupo dirigido.

Quais são essas qualidades, entre outras?

Saber para convencer

Moral para exemplificar-se

Saúde para enfrentar os trabalhos

Compostura para evitar críticas

Trajar-se discretamente para uniformizar-se ao grupo

Falar pouco para reservar-se

Admoestar em particular para não desvalorizar o par Conter-se nas atividades físicas para cultivar o equilíbrio Refletir ininterruptamente para estimular o mesmo nos pares

Ser cavalheiro para desenvolver o trato pessoal

Investigar continuamente para instigar

Polidez para humanizar o relacionamento médicopaciente

Organizar-se para progredir

Amar a instituição para o culto pátrio às atividades e ao patrimônio público

Cultivar a bondade para estimular o sentimento caridoso

Em sendo caridoso, tornar-se um benfeitor

Em fazendo o bem, ser um Médico

Três verbos fazem parte do seu trabalho: Ser, Ter e Dever 


\section{SER}

Competente

Compromissado

Presente

Cordial

Autêntico

Ético

Criativo

Líder

Enérgico

Bondoso

Ilibado

Justo sem conivência

Trabalhador

Discreto

Sociável

Filantropo

Culto sem ostentação

Patriota

Enfim, há que possuir o Dom

\section{TER}

Imaginação

Reserva no falar

Prudência (nas ações)

Atitude

Respeito pela Instituição

Autoridade

Humildade para mudar ou rever

Aparência agradável

Riqueza de alma

Coerência

Lisura no trato pessoal

Paciência nas dificuldades

\section{DEVER}

\section{Deve:}

Superar dificuldades

Dirigir com equilíbrio

Administrar com honradez

Cobrar atividades

Sugerir ideias

Mediar conflitos interpessoais

(incompatibilidade)

Doar tempo e sacrifício

Ouvir mais do que falar

Saber captar recursos

Exercer a caridade (desprendido)

Cumprir o dever

Conduzir o processo didáticopedagógico 